\title{
A Panpsychist Panentheistic Incarnational Model of the Eucharist
}

\author{
James M. Arcadi
}

\section{Introduction}

According to the guidance of the seven Ecumenical Councils as explications of the Christian Scriptures, Christianity teaches not only that there is a God, but that this God is triune and that one member of this Trinity has become incarnate in the person of Jesus Christ. Traditional explications of this teaching show Christ as being both fully God and fully human, while remaining only one person. That is, whereas most everything else in the cosmos only has one nature, Christ is unique among entities in having two natures-divinity and humanity. Hence, Christ is properly named »Emmanuel, «»God with us.« When one turns to Christian practice to find those instances wherein humanity's encounter with God is most profound, the Eucharist serves as the pinnacle of Christian worship and-or, perhaps, because of - a direct encounter with God. This is because the majority opinion teaching of the Christian tradition has it that in some fashion Christ - the God-human-becomes so related to the mundane elements of bread and wine, that the predications »This is the body of Christ « or »This is the blood of Christ« become warranted. Hence, the tradition teaches an increasing concretizing of God's being with humanity: in the cosmos, in Christ, and in the Eucharist.

What is not laid out explicitly in the Christian Scriptures or the pronouncements of the Councils, are specific statements regarding the ontology of the cosmos. The Christian theologian, then, is free to pursue fine-grained expositions of ontology that can be said to fall within the more thick-grained determinations of these authoritative sources. ${ }^{1}$ Hence, well-intentioned Christians have pursued such radically distinct fundamental ontologies as idealism, dualism, and materialism as possible ideologies within which to make sense of the Scriptural and Conciliar material. This essay proposes a route for explicating a model of the Eucharist - and its Christological infrastructure - within a panpsychist panentheistic ontological framework. Hence, the model offered here

1 On the distinction and relation of fine-grained and thick-grained explanations in theology, see Arcadi 2018a. 
is a hypothesized conclusion of the conjunction of numerous conceptual data points (all of which will receive further elaboration anon), including:

1) The Christological determinations of the seven Ecumenical Councils. ${ }^{2}$

2) A Corporeal Mode model of Christ's presence in the Eucharist. ${ }^{3}$

3) Panentheism.

4) Panpsychism.

In order to explicate this model of the Eucharist, each of the aforementioned data points must be laid out and explained. Since a description of the Eucharist is the telos of this essay, I will first set out some key distinctions and desiderata within the Eucharistic sphere of inquiry. Because the model of the Eucharist I favor utilizes the metaphysical infrastructure of Conciliar Christology, I will in the section following discuss these conceptual guidelines and show how they are brought to bear on the Eucharist. Subsequently, I will briefly discuss both panpsychism and panentheism. This will give rise to a discussion of how the Incarnation may be understood within a panpsychist and panentheistic framework. Finally, I bring all the data points to bear on the Eucharist in order to construct a panpsychist panentheistic incarnational model of the Eucharist.

\section{Preliminary Framework}

\subsection{The Eucharist}

According to the accounts of Christ's life from the Synoptic Gospels, Paul's letter to the Corinthians, and in light of the liturgical traditions of broadly catholic Christianity, on the night before he was handed over to suffering and death, Jesus Christ took bread, blessed it, gave it to those with him, and said, »Take, eat, this is my body.« Likewise, Christ took some wine, similarly blessed it, similarly gave it, and similarly said, »Drink this all of you; this is my blood of the new covenant. $\ll^{4}$ How properly to understand these locutions, however, has been the subject of no small amount of controversy over the course of the history of Christian theological reflection.

2 What has been called in the recent analytic theological literature, »Conciliar Christology.« See Pawl, 2016.

3 This terminology will be explicated further on and is derived from Arcadi 2016a: 402-412. For the record, my most thorough examination of the Eucharist comes in Arcadi 2018a. For a discussion of models of the Eucharist within an idealist ontological framework-and hence, support for the claim that one may realize at least one aspect of the traditional teaching of Christian theology within different ontological frameworks-see Arcadi $2016 \mathrm{~b}$.

4 The most relevant Scriptural pericopes are: Matthew 26:26-28, Mark 14:22-25, Luke 22:17-20, I Corinthians 11:23-26. 
As I see it, the traditional explanations of these words fall into three main families. First, we might designate those interpretations that join the bread and the wine in a metaphysically-robust sense to the body and blood of Christ. These are, as I call them Corporeal Mode explications of Christ's presence in the Eucharist. This is the majority opinion family of views in the tradition and the genus under which my specific model will fall, hence further discussion of this family will come further on. ${ }^{5}$ Another family of views on the relation between Christ and the elements of bread and wine is the Pneumatic Mode. ${ }^{6}$ This family emphasizes a spiritual connection between either Christ and the elements or Christ and the recipient by means of the elements. Finally, a third family of views I refer to as the No Non Normal Mode. ${ }^{7}$ This mode states that there is no more significant connection between Christ and the elements or Christ and the recipient of the elements by means of the elements than is found in any other locale in the cosmos. Perhaps one or more of these modes would fit more or less easily within a panpsychist panentheistic framework, but due to its popularity in the tradition, this essay pursues a species of a Corporeal Mode explication of Christ's presence in the Eucharist.

The Corporeal Mode family of views can be further subdivided into three main descendants: transubstantiation, consubstantiation, and impanation. The former can be defined as holding to the twin beliefs that after the consecration of the bread and the wine, the consecrated object is (a) no longer bread or wine, yet is (b) the body or blood of Christ, respectively. These metaphysical claims, however, obtain with no corollary empirical change in the consecrated objects. The objects remain empirically the same prior and subsequent to the consecration of these elements. What does change is the underlying reality of the objects. The proponent of consubstantiation-found, not by that name, in many Lutheran quarters - holds (b) with the transubstantiation theorist, but does not endorse (a). That is, the consubstantiation theorist holds that the body and blood of Christ comes to be located »in, with, and under ${ }^{8}$ the bread and the wine. Yet in addition to retaining all their empirical qualities, the

5 Specific communions that tend, either implicitly or explicitly, to endorse proposals in this family are the Eastern Orthodox, Roman Catholic, Lutheran, and some Anglican traditions.

6 Representative examples from the tradition of views falling in this family are the Reformed theological descendants of John Calvin, some Anglicans, and Methodist theological descendants of John Wesley. It is a point of dispute in the history of interpretation, but I would place views inspired by the 2oth century Roman Catholic theologian Edward Schillebeeckx in this latter category as well. For discussion, see Arcadi 2016a and Arcadi 2018b.

7 This view is largely found among the theological descendants of Ulrich Zwingli including but not limited to-some Reformed, Baptistic, Pentecostal, and Free Church traditions.

8 As the traditional Lutheran quip goes. 
consecrated objects remain bread and wine. Finally, like consubstantiation, the impanation theorist holds to (b) but not (a). However, what differentiates impanation from consubstantiation is the desire of the proponent of impanation to offer an account of the union between the bread and the body of Christ — or the wine and the blood of Christ — in a manner patterned after the Incarnation. It is my contention here-as elsewhere-that impanation is to be preferred as most adequately satisfying the Scriptural, liturgical, linguistic, metaphysical, and theological desiderata pertaining to the presence of Christ in the Eucharist. ${ }^{9}$

Although transubstantiation, consubstantiation, and impanation are all Corporeal Mode cousins, there are subtle differences between them. What is desired by Scripture and the liturgy is a metaphysical state of affairs such that it is apt to say of the consecrated bread, »This is the body of Christ. «10 Each Corporeal Mode view attempts to offer such a metaphysical state of affairs. The transubstantiation theorist holds that the best way to secure the aptness of this predication is to hold that the post-consecration consecrated object is no longer bread. Oftentimes, in the Roman Catholic tradition this phenomenon is exposited with recourse to an Aristotelian substance ontology. However, this is not a necessary feature of the official Roman Catholic position. What is necessary for the Roman Catholic is the denial of the continued presence and existence of the bread, post-consecration.

My purpose in this essay is not to show the necessary falsity of nonimpanation views of the Eucharist. Hence, I briefly just gesture in the direction of a response to the transubstantiation model. I do so by raising the question of: to what does »this « in the sentence »this is the body of Christ « refer? It is not the object empirically and phenomenally present to potential recipients, for that is merely the empirical features of bread, which the object no longer is. If the indexical refers to the body of Christ, we might reasonably ask about just where this body is? Aristotelian substance ontology has been deployed to argue that while the accidents of the bread remain where and what they always are, the substance of the bread changes to become the substance of the body of Christ. But then one is forced to accept the severing of the relation between substance and accident that is the bedrock of that ontology. Absent this modification to this ontology, we are left wondering just what »this« is. ${ }^{11}$

9 This is, of course, absent the constraints of the official teaching of the Roman Catholic magisterium.

10 I will here focus on the bread and the body of Christ; a similar analysis applies, mutatis mutandis, for the wine and the blood of Christ.

11 Of course, modifying Aristotelian substance ontology is just what the medieval schoolmen did. See McCord Adams 2010. Again, my purpose is not to show the necessary falsity 
A similar linguistic — and then by extension metaphysical — query can be raised in regard to the consubstantiation theory. The theorist in this camp typically holds that the body of Christ comes along with the consecrated bread to be consumed by the recipient. What is oftentimes lacking in this sphere of explanation is a robust account of the union between the consecrated object and the body of Christ. »With-ness, « if it even meets the vagueness objection, does not seem to be any more intimate a relation than co-location. While this view can provide for the reality of the empirical features of bread in the consecrated object — because it is still indeed bread—it does not seem as though this view can countenance the predication that this object, »this, « is the body of Christ. Rather, on this construal, »this« refers to some imperceptible entity co-located with the bread. Yet, the bread is what draws the attention of the recipients and the bread is that which the minister holds and says, »this is the body of Christ." More specifically speaking, if this metaphysical situation were apt, the minister should refer to the bread and say, »the body of Christ is around here.«But this, of course, is not what ministers following the catholic liturgies, following the words of Scripture, in fact say.

By contrast, impanation has the virtues of both countenancing a natural interpretation of the indexical and reusing a metaphysical infrastructure with the weight of Ecumenical Councils behind it. According to the traditional teaching regarding the Incarnation, the faithful are to say both that Jesus Christ »is God « and that he »is a human being, « while remaining one person. Hence, unity and duality are at the heart of the traditional teaching; Christ is unified in personhood, but dual in natures. In like manner, the impanation theorist holds that post-consecration the consecrated object is both bread and the body of Christ, yet remains unified by being only one object. In the Incarnation, the notion of the hypostatic union is deployed to describe the union between the divine nature and an instance of human nature. In a similar manner in impanation, the notion of a sacramental union is deployed to describe the union relation between the bread and the body of Christ. Hence, the impanation theorist holds that the metaphysical state of affairs undergirding the predication of the bread that »this is the body of Christ, « is parallel to the metaphysical state of affairs undergirding the predication of Jesus Christ that »this is God.» As, however, should be clear by this paragraph, since impanation is based on a traditional explication of the Incarnation, we must first offer an examination of that doctrine.

of non-impanation views, but rather to show that there are more attractive features to this view in just those places where others are less attractive. 


\section{$2.2 \quad$ The Incarnation}

Anyone who reads the Christian Scriptures with the grain of the determinations of the seven Ecumenical Councils will see that Christians think that Jesus Christ is both God and a human being. For instance, the, so-called, >Definition< of Chalcedon states:

Jesus Christ is one and the same Son, the Same perfect in Godhead, the Same perfect in manhood, truly God and truly man, the Same [consisting] of a rational soul and a body; homoousious with the Father as to his Godhead, and the Same homoousious with us as to his manhood ... made known in two natures [which exist] without confusion, without change, without division, without separation ... concurring into one Person and one hypostasis- not parted or divided into two persons, but one and the same Son ... the Lord Jesus Christ. ${ }^{2}$

This statement, among others in Scripture and the proceedings of the Councils, gives rise to the two-natures doctrine - that one member of the Trinity is incarnate as Jesus Christ, being one person with two natures. How to understand this doctrine, and defend the logical coherence of it, has been the focus of much recent work in analytic theology.

In tracing the conceptual frameworks in the analytic literature's discussions of the two-natures doctrine, we can see a number of streams of explication. For instance, Jonathan Hill delineates a first branching of the Christological tree between those who hold to transformationalist models of the Incarnation from those who hold to relational models of the Incarnation. For the transformationalist, when the Christian tradition says that the second person of the Trinity became human, »to become human means being transformed into a human ... just as a caterpillar becomes a butterfly by being transformed into one. ${ }^{13}$ However, one worry that might be raised to this explanation is that, on the analogy of a butterfly, once the caterpillar is transformed into a butterfly it ceases to be a caterpillar. If the second person of the Trinity were transformed into a human and ceased to be divine, then we would no longer have a twonatures doctrine of the Incarnation, as Conciliar Christology seems to require. Moreover, following the theo-logic of panentheism, we might see the transformationalist view as not being apt. On panentheism, much of God remains beyond or outside the cosmos, but then by application to the Incarnation, in the Incarnation we would want some or much of God to remain beyond or

12 Coakley 2002: 143.

13 Hill 2011: 8. 
outside the human nature in Christ. ${ }^{14}$ Hence, the two-natures proponent may go looking for other models to describe the Incarnation.

A second family of views on the Incarnation in the recent analytic literature are called relational views. These views typically hold that the second person of the Trinity —in the Incarnation-comes to be related in a particularly intimate way with a concrete particular that is an instance of human nature. Hence, on this view, Christ is composed of two concrete natures, the divine nature and an instance of human nature. Thus, this view is also termed »concretecompositionalism.«Given the panenthesistic framework to be sketched, we must specify that this view is relational by God in Christ being more intimately related to a segment of the cosmos than is God's normal modus operandi. The panentheist is always going to think that God is related to the cosmos in a particularly intimate way (more on this anon). What occurs in the Incarnation, then, must be either of a different kind or different intensity of relation than is God's relation to other parts of the cosmos. Yet, just what this relation is and how it might differ from God's general relation to the cosmos remains a bit obscure.

There is a potential mediating position between transformationalist and relationalist views, even as it might be characterized as one or other of the two. This view can be referred to as an »additionalist « perspective. ${ }^{15}$ The idea here being that the second person of the Trinity merely »adds on « whatever necessary and sufficient features for being human are requisite. In this manner, the second person need not transform into a human and thus cease to be divine. Nor, however, does one need to hold that the second person becomes related to something somehow somewhat independent of the second person. Rather, whatever it is to be a human can be added on to the second person of the Trinity such that this person can properly said to be both divine and human. As will be seen further on, this is the most promising route of explication for Conciliar Christology within a panpsychist framework.

\subsection{Panentheism}

I turn now from Christology to panentheism. Panentheism is a theory about the nature of God and God's relation to the cosmos. However, there does not seem to be a consensus in the tradition or the contemporary literature as to

14 The notion of the second person of the Trinity extending beyond the human nature sometimes falls under the doctrinal heading of the (somewhat anachronistically termed) extra Calvinisticum. For a helpful historical theological examination of this doctrine, see McGinnis 2014.

15 See discussion in Arcadi 2018c. 
just how to characterize God or the God-cosmos relation. ${ }^{16}$ Hence, I want to here offer a brief apologia for a deflationary account of panentheism. A deflationary thesis about panentheism simply says that God exists, the cosmos exists, and the relation between God and the cosmos is sufficiently intimate to warrant the attribution of »in « of the cosmos to God. The panentheist can account for intimacy in this relation by a diversity of means: ontological, mereological, causal, axiological, teleological, or others. What I am keen to show, however, is that although how one characterizes the intimacy of this relation has bearing on how one conceives of the nature of God, this bearing need not be taken as necessity. And thus a number of very disparate views on the nature of God and God's attributes can be held in conjunction with the deflationary panentheistic thesis.

For instance, deflationary panentheism can allow for such disparate conceptualizations as either the strong divine immutability of classical theism or the strong divine mutability of process theism, and just about everything in between. The distinction turns not necessarily on the nature of God, but on the nature of the cosmos. If the deflationary panentheistic thesis is granted, and one has a corollary commitment to, say, four-dimensional eternalism, one can still seemingly preserve strong divine immutability. This picture would have it that there exists God and in God is a four-dimensional whole that presentlyfrom the divine present - contains all that there was, is, and will be, from our phenomenal experience. This can be as strongly a hard determinism, with a related strong divine immutability, as one likes. Likewise, on the contrary, one can lodge a presentist view of time within the deflationary panentheistic thesis and articulate a divine that is as changing, shifting, and mutable as the process theist likes. To determine one extreme or the other, or something in between, is not settled by accepting or demurring from panentheism.

A properly Christian appropriation of the panentheistic model of God's relation to the cosmos must remain faithful to the creedal affirmations regarding the Trinity and the Incarnation, as well as the creaturely dependence relation the cosmos has on God as denoted in the first clause of the Creed. A project — such as this present study — that attempts to maintain fidelity to the Christological teachings of the Ecumenical Councils would be inconsistent if it did not maintain fidelity to the non-Christological teachings of those Councils as well. However, assenting to the creaturely status of the creation, does not necessarily rule panentheism out from the start. Rather one can maintain this notion with an understanding of panentheism as well. Göcke characterizes

16 See especially the helpful discussion in Mullins 2016 and Göcke 2012. 
panentheism in this way: »Although there is a distinction between God, as the ultimate ground of reality and reality itself, a distinction that is epistemologically needed for ultimate explanation, there cannot be a substantial ontological distinction between them. «17 The conjunction of a thesis about God's status as creator and the non-substantial ontological distinction between creation and creator do not need to be seen as entailing a contradiction. Rather, one can hold that the creation was brought into being out of God's own being.

This conception might seem to push against the traditional Christian notion of creatio ex nihilo. However, this need not be the case. This standard phrase can easily be interpreted to hold that God created out of nothing distinct from Godself, as if there were some entity or entities co-eternal with God from which God fashioned the creation. ${ }^{18}$ One does not need to hold that creation out of nothing entails that "nothing « is some space or area outside of God from whence God created the cosmos. Rather, the concern in this line of inquiry has to do more with God's aseity than the process of creation. The Christian panentheist can maintain God's aseity just as firmly as the classical theist, if she so wished. And hence she can similarly endorse the doctrine of creatio ex nihilo - which is ordered to this end-just as much as the classical theist; again, if she so wished.

One plausible mode for explicating the intimacy of the relation between God and the cosmos-an intimacy sufficient for holding the cosmos to be »in« God-is a causal mode. God is in the cosmos in that God is fundamentally and continually causing the cosmos whose existence is necessarily dependent on this divine causal activity. Drawing on my action model of God's omnipresence, Georg Gasser makes the causal relation between God and the cosmos one of the central planks in his account of panentheism. ${ }^{19}$ According to Gasser, a traditional way of explicating God's omnipresence has been to see God's presence in a threefold manner: by God's knowledge of all things, by God's providential conservation of all things, and by God's being the author of the nature and existence of all things. ${ }^{20} \mathrm{My}$ account of omnipresence holds that the second manner, God's causal activity, is all that is requisite to get an explanation of omnipresence off the ground. For Gasser, panentheism is such that, $»$ All of creation is within the sphere of God's creative, sustaining and caring agency or it

\footnotetext{
17 Göcke 2017: 6.

18 Here the recent discussion around the relation between God and abstract objects is paramount. See, for instance, Craig 2016.

19 Gasser 2019: 43-62 and Arcadi 2017.

20 Gasser 2019: 57.
} 
is not at all.«21 Being »within the sphere of,«for Gasser, is sufficient to capture the »in « of panentheism. This causal account is but one among many ways of characterizing deflationary panentheism, but it will be particularly useful for my explication of the Incarnation and the Eucharist within a panentheistic framework. However, before we turn to the task of conjoining panentheism, the Incarnation, and the Eucharist, I have next to discuss the final data point of this hypothesis, panpsychism.

\subsection{Panpsychism}

Similar to panentheism, if one asks ten philosophers of mind about the nature of panpsychism, one will likely get a dozen different answers. Hence, all I can do here is to adopt a version of panpsychism that seems to have particular potential for my Eucharistic aims. The fundamental tenet of this ideology is that each and every object in the cosmos is composed or constituted by mentality (or proto-mentality) and physicality. Call this a monism, call this dualism all the way down, call this something else, but the basic idea is that mentality is ubiquitous in the cosmos. The basic motive for panpsychism is that it certainly seems as though we humans have phenomenal consciousness that is not reducible to purely physical entities. However, a pure or simple dualism is fraught with many issues. Hence, if like comes from like, then this consciousness or mentality or proto-mentality must be a part of the whole cosmos since it is part of at least one part of the cosmos, namely humans.

I take it that the microexperiences of less complex subjects can fuse together into more complex objects with governing macroexperiences. In an analogous manner as we think of the human body as a complex system of nerves, bones, blood, and flesh, the human mind (related to these bodily parts) arises as a macroexperiencer out of the microexperiences of its constitutive parts. This entails, however, that one can find consciousness or proto-consciousness at all manner of varying levels of complexity. Whether objects vastly less complex than animals like rocks, bread, or wine actually have consciousness is up for interpretation and debate, but the determination of this discussion is not relevant for my purposes. All that is needed is that mundane objects have at least some level of mentality or proto-mentality that can be incorporated into larger complexes that do clearly have macroexeperiences.

21 Gasser 2019: 6o. 


\section{Conjunction of the Preceding}

In what follows I draw together the various conceptual strands relating to panpsychism, panentheism, Christology, and the Eucharist.

\subsection{Panpsychist Panentheism}

This volume in its entirety is about just this topic of this section, the conjunction of panpsychism and panentheism. Accordingly, I will not offer an exhaustive discussion of the implications of this conceptual marriage outside what is specifically required for the Eucharistic task at hand. As there are multiple ways to construe panpsychism and there are multiple ways to construe panentheism, so too are there multiple ways to construe a panpsychist panentheism. I suggest but one way here which, prima facie, fits the other conceptual data points of the current essay.

When we discuss panentheism, we are inquiring into how the cosmos is in God. When we fuse this view to panpsychism, we begin to inquire how God is in the cosmos. As indicated above, one plausible way to construe panentheism is through the continuous and fundamental causal activity of God at every location in the cosmos. This would entail that God is causally active on each and every object in the cosmos, no matter how simple or complex, small or large. I propose that at least one action God performs on the cosmos is to push simple objects into configurations of greater complexity. That is, God acts teleologically on the cosmos to push (or pull) a trajectory of ever-increasing complexity. One can easily overlay this story onto an evolutionary narrative whereby the history of the cosmos includes the emergence of ever increasingly complex animals and systems, presently culminating in humans as the most systematically complex entities in the cosmos (so far as we know). On this view, everything is in God because God is in everything causally pushing (or, one might say, teleologically pulling) the fundamental mentality or protomentality of all objects toward greater complexity.

However, given the theism of the Ecumenical Councils, since God is the fundamental entity, and God Godself is a mental entity, it might seem as though it would be God's mentality that is at the core of every mental-physical object. How can a panpsychist panentheism avoid the entailment that there is only God's mentality in the cosmos and the presence of non-divine mentality is merely an illusion?22 What blocks panpsychist panentheism from collapsing into pantheism? I propose that one way to block this entailment is to hold that in order for a system to be identified with an agent, that agent itself must 
identify with the system and take ownership of the system as its own. Systems of higher complexity—say, humans — are capable of incorporating systems of lesser complexity into their system. This routinely happens when humans use tools and also occurs in such mundane instances as wearing clothes, eating breakfast, and brushing one's teeth. The incorporation of other objects into one's own human system occurs by means of a causal connection between the agent and the object. When the object is in use by the agent, the object becomes part of the agent's system and-even if for a time-is a constitutive component of a system more complex than itself.

A sycamore tree in my yard has, on the panpsychist proposal, mentality or proto-mentality. If, however, I were to take a branch from the tree, attach it to my body and utilize it as another leg, that branch would be incorporated into my body. As I had taken ownership of the branch, I could then identify it as part of me and it would indeed become part of my psycho-physical system. In my causal connection to the branch, taking ownership of and identifying with the branch, it would be proper to say of the branch that it is part of me, and that it is me. Conversely, with the cosmos and God, although God is continually acting on each and every object in the cosmos, supplying it with existence, mentality, and pushing it toward greater complexity, God does not identify with or take ownership of each and every object. But were God to do so, then that object would indeed become God. Since God is the source of each and every object in the cosmos, so I propose, God reserves the prerogative to intensify God's causal union with each and every object, and take the requisite kind of ownership needed for God to identify Godself-at least in part—with the newly owned object. On this hypothesis, God is continually acting on the created realm. God does this (a) in order to sustain it in existence, (b) to provide the mental component that is paired with the physical as is necessary in the panpsychic worldview, and (c) to push the creation »upwards « into greater complexities of macroexperience, culminating in human beings. When fusing this view with traditional Christology, we arrive at one particular human being on whom this activity reached a unique height, the height of Incarnation.

\subsection{Panpsychist Panentheistic Christology}

Traditional Christology has it that the phenomenal experience had by Christ was and is had by God Godself. In fact, this statement is a tautology for the one who accepts Conciliar Christology. A panpsychist panentheism opens up the conceptual space to show how God could take on the consciousness of any component of the cosmos. There is no requirement that God take on the experiences-micro or macro-as God's own of the cosmos. But there is no prohibition either. God is free to act as much or as little as God likes in any 
given situation. Because of the radical dependence relation of the creation on the creator, God could simply cease acting on some segment or other of the cosmos and it would cease to exist. However, conversely, God is able to intensify God's actions as well. And this intensity could reach the point at which God even took on the phenomenal experiences of some complex segment of the cosmos as God's own. This, we might say, would be a divine incarnation. And if it were to occur by way of a complex segment of the cosmos that meets the necessary and sufficient conditions for being human, this would be an divine-human incarnation. When we say that a divine-human incarnation has in fact occurred in the person of Jesus Christ, then we have finally arrived at the Incarnation of Christian teaching.

Within the contemporary analytic literature on Christology, this would be an additionalist model of the Incarnation. God could add on any segment of the cosmos as God likes in this incarnational manner. God does not need to transform into some segment of the cosmos, but nor does it need to be said that God merely becomes related to some segment of the cosmos. Rather, the additionalist conception of Christology has it that God adds on the phenomenal perspective of the human nature of Christ. Moreover, the additionalist Christological motif might in some way even parallel how the panentheist tends to think of the relation between God and the cosmos. We might say that God adds on the cosmos to Godself, within Godself. Like the second person of the Trinity additionally becomes human, so too at creation does God additionally include the cosmos. Consequently, we have a harmonious conceptual framework for thinking of both the divine-cosmos relationship and the relationship between the divine and human natures in Christ.

Here, then, is a panpsychist-panentheistic just-so story of the Incarnation: God, from Godself, creates the cosmos and continually exercises causal power on each and every object in the cosmos. Each and every object in the cosmos is a mental/physical hybrid, which is ontologically dependent on the causal power supplied to it by God. The microexperiences of the most simple objects can join together to form macroexperiences when the simple objects are joined up into a system of greater complexity. Such is, then, the emergence of human consciousness as a complex system. As the ontologically highest entity in which the cosmos is, God has the fundamental right to take ownership of each and every object and identify its phenomenal experiences as God's own. God does this by intensifying God's causal power exercised at the location of an object. God is present by causal power, and hence God can be more present by causal power. If God were to intensify God's causal power at a location to the point of taking ownership of the object at that location, that object would become God. This could happen with as simple or as complex a system 
as God likes. This has occurred in the person of Jesus Christ. God has added on the complex human system with its attendant macroexperiences that is the human nature born of the Virgin Mary. That object, the human nature born of the Virgin, remains a human nature despite its incorporation into the divine in a unique way. But the incorporation that is Incarnation also makes it such that it is proper to point to Jesus Christ and say, »This is God« in a manner inapt for other objects in the cosmos. Hence, it could be said, the panentheistic God has become incarnate in the panpsychist complex that is the human nature of Jesus Christ. God added on the human nature of Christ. God was always in us, as we are always in God, but in the Incarnation God became with us, as God became one of us, in Emmanuel.

\subsection{A Panpsychist Panentheistic Incarnational Model of the Eucharist}

With this brief account of the Incarnation within a panpsychist panentheism in place, we can finally apply all the preceding data points to the Eucharist. In the Eucharist, God is not just in us in a general causal sense; God is with us in a specific sense in the consecrated bread and wine. As indicated previously, I find the impanation view the most satisfying for a variety of reasons, not the least of which is the manner it comports with incarnational thinking. This is what will be expounded here. However, there are at least two routes by which one might apply the preceding to the issue of the presence of Christ in the Eucharist. Elsewhere I have called versions of these two routes »Hypostatic Impanation« or »Type-H Impanation« and »Sacramental Impanation« or »Type-S Impanation. «23 The distinction between these two views turns on which aspect of the incarnate Christ the bread and wine are related. That is, Eucharistic views like impanation attempt to characterize a relation that brings about the aptness of the statement, »This is the body of Christ.« One side of the relation is clearly the consecrated elements. The other relatum is different for Type-H or Type-S Impanation. For Type-H, the second relatum is the divine second person of the Trinity; hence, here the relation between the elements and the second person of the Trinity circumvents the human nature of Christ. For Type-S, the second relatum is the human body of Christ; hence, here there is a chain - of sorts-from the divine second person of the Trinity through the human nature of Christ to the consecrated elements. I will next describe each view in kind and then offer a brief assessment.

23 See Arcadi 2018a and 2015: 75-90. 
Type H Impanation

Above I sketched the notion that God has the ultimate prerogative to take ownership of any segment of the cosmos and identify it as God's own self. God does not do this, for this preserves the distinction of (most) of the cosmos (except Christ) from Godself and thus does not entail pantheism. Yet, this is just what the second person of the Trinity does in the Incarnation. God intensifies God's causal activity at the location of the human nature of Jesus Christ, takes ownership of it, and identifies with it such that it warrants the predication, »This is God« when spoken of Christ.

The same situation could apply to the consecrated bread and wine and this is just what Type-H avers occurs in the Eucharist. God intensifies God's causal activity at the location of the bread and wine, takes ownership of it, and identifies with these objects. God would then take ownership of the phenomenal perspective offered by these objects, and this perspective would become God's perspective. This might be termed another incarnation of God in another location in the cosmos. The structure and relative complexity (or relative simplicity) of the bread and wine would dictate what God could do as the bread and wine. A human body, like what God adds on in the Incarnation, is a complex system that would allow God to walk, talk, eat, sleep, and do all manner of human activities as a human being. Bread and wine have no such complexity, nor potential actions. Nevertheless, this model grounds the traditional Christian notion that God is specially present in the consecrated bread and wine of the Eucharist.

\section{Type-S Impanation}

The Type-S theorist worries, however, that the Type-H view circumvents the human nature of Christ. On the Type-H view, God can intensify God's presence at any and every consecration. But this happens only on an analogy with the Incarnation, not because of or in relation to the Incarnation. Type-H seems to result in predications of the consecrated objects like, »This is bread« or »This is God« or even »This is the body of God.«But it depends on what one means by »Christ« whether Type-H is able to deliver on the Scriptural and liturgical utterance, »This is the body of Christ. «If one took »Christ« to refer to the specific instance of Incarnation that is the adding on of the human nature of Christ's phenomenal experiences to God, then Type-H would not supply the metaphysical story for the state of affairs expressed by »This is the body of Christ. « But, Type-S would.

Type-S wishes to draw a specific connection between the human nature of Christ and the consecrated bread and wine. How would this work? God would need to conjoin the micro-experiences had by the bread and the wine to the 
system that is the human nature of Christ. Christ's human nature, then, would be extended beyond the bounds of its organic human body to include objects non-organically connected to his human body. ${ }^{24}$ Despite these objects distance from the human body of Christ, they would nonetheless be joined by divine power to the human phenomenal experience of Christ. As the human body just is the locus of human phenomenal experience, then these objects would properly be considered parts of the human body of Christ. This would, of course, then sanction the liturgical utterance made of the consecrated bread, »This is the body of Christ.«

The symmetry of this model with my illustration of the sycamore tree branch above should be clear. The consecrated bread and the wine become instruments or tools of the human nature of Christ. In this manner, as in other instances of bodily extension or prosthesis use, the instruments become parts of the body of Christ and are aptly named as such. The distinction, however, between the Type-S explication of Eucharist and the sycamore branch illustration is the lack of physical contiguity between the consecrated elements and the human nature of Christ. However, I do not see the lack of physical contiguity as an obstacle for the view. Given a panpsychist and panentheistic framework, God merely needs to conjoin the phenomenality of the consecrated elements to the phenomenality of Christ's human nature. This fusion of mentality or proto-mentality of seemingly discontinuous objects, then, fuses the objects themselves. When this conjunction is instantiated and a causal connection between Christ and the consecrated elements occurs by means of this conjunction, the liturgical utterance is warranted: this — this bread—is the body of Christ.

\section{Assessment of Both Views}

Both of these impanation theories are able to deliver on a concentration of God's presence at the location of the consecrated bread and wine. Both, in different senses, would be able to deliver on the conception of the bread and wine being the body of God. Type-S is to be preferred, however, if one held »Christ« to be a specialized term denoting only the incarnate activity of the Second Person of the Trinity in the human nature of Christ. If one is attempting to draw a tight connection between the historical body of Christ (born of the Virgin, suffered under Pontius Pilate, raised on the third day, etc.), then, for my money, Type-S is the preferred route. However, Type- $\mathrm{H}$ is not without

24 This might seem a stretch, but the literature on the Extended Mind Thesis (EMT) is now vast and has obvious points of contact with the narrative adduced here. For further application of the EMT to the Eucharist, see Arcadi 2015. 
merit and is worthy of consideration. Here I simply raise two other brief considerations.

First, one might wonder whether having the phenomenal experiences of consecrated bread and wine would entail feeling great pain at being chewed and digested. However, there should be no worries about Christ feeling the pain of being manducated. The sensation of pain-so far as we understand it-requires a much more complex configuration of matter than we see in the combination of flour, water, yeast, oil, and salt. ${ }^{25}$ The human body that the second person of the Trinity assumed at the Incarnation provided an appropriately complex configuration of matter such that in virtue of his human nature Christ did feel the pain of the Passion. But there is no requirement on the present Eucharistic model — or any model of impanation — that Christ feel pain by way of the faithful's teeth. Bread and wine just cannot supply the kind of phenomenal experience as a human body can.

Second, given the incorporation of the bread and wine into the body of Christ, does the bread and wine cease to be bread and wine? That is, do the impanation models I have sketched collapse into transubstantiation? From one angle, I see no reason the transubstantiation theorists could not help themselves to much of what I have described as impanation within a panpsychist panentheistic incarnational framework. They too could argue that the predication »this is the body of Christ« is apt due to the requisite concentration of divine activity that »elevates « the microexperiences of the elements to a sufficiently high level. However, at this point in the analysis it does not seem that the distinction between transubstantiation and impanation can be made on the basis of philosophical reasoning alone. Rather the transubstantiation theorist will assert the determinations of the Roman Catholic magisterium to say that we may no longer call the consecrated object »bread « post-consecration. On the contrary, the impanation theorist will aver that the theo-logic of the Incarnation that provides the metaphysical infrastructure for the aptness of the predication pushes the faithful to maintain the reality of the bread in the same way as Christ is both God and a human being. The dispute here, to me, seems intractable and one will simply have to decide whether they will choose the conception of their ancestors, or choose the view of those in whose land they dwell. But as for me and my house, we will choose a version of impanation.

25 These are the traditional ingredients in Eucharistic bread. For a fascinating theological study of the materiality of the Eucharist, see Grumett 2016. 


\section{Conclusion}

Panentheism teaches that God is in us insofar as we and all things are in God. Christianity teaches Emmanuel, that God is with us in the person of Jesus Christ. The Eucharist has long been held to be a unique way that God is with humanity. Hence, as indicated from the outset, this progression from panentheism to Incarnation to Eucharist indicates an ever concretizing and ever localizing experience of God's presence with humans. Although in some sense any view of the divine that includes the attribute of omnipresence entails the possibility of encounters with God anywhere, Christian teaching has it that the Eucharist is a direct encounter with God; the Eucharist is literally an instance of Emmanuel, of God with us. This essay has sketched how this might be said to be so within a panpsychist panentheism. It should not be forgotten, however, that in addition to making it such that God is with us, the Eucharist is intended by Christ to be consumed by the faithful. Thus, the Eucharist becomes a unique way that - even as we are in God-God is in us.

\section{5. $\quad$ References}

Arcadi, J.M. (2015) »Impanation, incarnation, and enabling externalism.« Religious Studies 51(1), 75-90.

Arcadi, J.M. (2016a) »Recent philosophical work on the Eucharist.« Philosophy Compass 11(7), 402-412.

Arcadi, J.M. (2016b) »Idealism and participating in the body of Christ.« In: J. Spiegel, J.R. Farris, and S.M. Hamilton (eds.) Idealism and Christian Theology. New York: Bloomsbury Academic, 197-215.

Arcadi, J.M. (2017) »God is where God acts: Reconceiving divine omnipresence.« Topoi $36(4), 631-639$.

Arcadi, J.M. (2018a) An Incarnational Model of the Eucharist. Cambridge: Cambridge University Press.

Arcadi, J.M. (2018b) »Redeeming the Eucharist: Transignification and Justification.« M. Cortez, J.R. Farris, and S.M. Hamilton (eds.) Being Saved: Explorations in Soteriology and Human Ontology. London: SCM Press, 233-245.

Arcadi, J.M. (2018c) »Recent developments in analytic Christology.« Philosophy Compass 13(4), 1-12.

Coakley, S. (2002) »What Does Chalcedon Solve and What Does It Not? Some Reflections on the Status and Meaning of the Chalcedonian >Definition<.« In: S.T. Davis, D. Kendall, and G. O'Collins (eds.) The Incarnation: An Interdisciplinary 
Symposium on the Incarnation of the Son of God. Oxford: Oxford University Press, 143-163.

Craig, W.L. (2016) God Over All: Divine Aseity and the Challenge of Platonism. Oxford: Oxford University Press.

Gasser, G. (2019) »God's omnipresence in the world: on possible meanings of >en< in panentheism. « International Journal for Philosophy of Religion 85, 43-62.

Göcke, B.P. (2020) »Panpsychism and Panentheism.« In: This Volume, 37-63.

Göcke, B.P. (2012) »Panentheism and classical thesism.« Sophia 52, 61-75.

Göcke, B.P. (2017) »Concepts of God and models of the God-world relation.«Philosophy Compass 12, 1-15.

Grumett, D. (2016) Material Eucharist. Oxford: Oxford University Press.

Hill, J. (2011) »Introduction.« In: J. Hill and A. Marmodoro (eds.) The Metaphysics of the Incarnation. Oxford: Oxford University Press.

McCord Adams, M. (2010) Some Later Medieval Theories of the Eucharist: Thomas Aquinas, Giles of Rome, Duns Scotus, and William Ockham. Oxford: Oxford University Press.

McGinnis, A.M. (2014) The Son of God Beyond the Flesh: A Historical and Theological Study of the extra Calvinisticum. T\&T Clark Studies in Systematic Theology vol. 29. London \& New York: Bloomsbury/T\&T Clark.

Mullins, R.T. (2016) »The difficulty with demarcating panentheism.« Sophia 55, 325-346.

Pawl, T. (2016) In Defense of Conciliar Christology: A Philosophical Essay. Oxford: Oxford University Press. 